\title{
PENGARUH KEPEMIMPINAN TRANSFORMASIONAL KEPALA SEKOLAH, KOMPETENSI, MOTIVASI DAN KEDISIPLINAN GURU TERHADAP KINERJA GURU SMK
}

\author{
Tokhibin, Wuradji \\ SMK Negeri 3 Magelang, Universitas Negeri Yogyakarta \\ tokhi10@yahoo.co.id,wuradji43@gmail.com
}

\begin{abstract}
Abstrak
Penelitian ini bertujuan untuk mengungkap pengaruh kepemimpinan transformasional kepala sekolah, kompetensi, motivasi dan kedisiplinan guru terhadap kinerja guru SMK di kota Magelang. Metode Penelitian menggunakan pendekatan kuantitatif dengan jenis penelitian ex-post facto. Responden penelitian adalah guru-guru SMK di kota Magelang sebanyak 89 orang. Pengumpulan data menggunakan angket terhadap guru. Pengujian validitas butir dilakukan dengan product momen pearson, sedangkan uji reliabilitas dengan menggunakan metode Alfa-Cronbach. Hasil analisis regresi linier sederhana menunjukkan bahwa kepemimpinan transformasional kepala sekolah meningkatkan kinerja guru (sig= $p<0,05 ; R_{\mathrm{yx} 1}=15,2 \%$ ); kompetensi guru meningkatkan kinerja guru (sig= $p<0,05$; $\left.R^{2}{ }_{\mathrm{y} \times 2}=51,8 \%\right)$; motivasi guru meningkatkan kinerja guru (sig= $p<0,05 ; R_{\mathrm{yx} 3}^{2}=53,9 \%$ ) dan kedisiplinan guru meningkatkan kinerja guru ( $\left.\operatorname{sig}=p<0,05 ; R_{\mathrm{yx} 1}^{2}=45,9 \%\right)$. Hasil analisis regresi linier ganda menunjukkan kepemimpinan transformasional kepala sekolah, kompetensi, motivasi dan kedisiplinan guru secara bersama-sama meningkatkan kinerja guru (sig = $p<0,05$; Adjusted $R_{\mathrm{yx} 1,2,3,4}^{2}=61,7 \%$ )
\end{abstract}

Kata kunci: kepemimpinan transformasional kepala sekolah, kompetensi guru, motivasi guru, disiplin guru, kinerja guru

\section{THE EFFECTS OF PRINCIPALS' TRANSFORMATIONAL LEADERSHIP AND TEACHERS' COMPETENCY, MOTIVATION, AND DISCIPLINE ON THE PERFORMANCE OF THE VOCATIONAL HIGH SCHOOL TEACHERS}

\begin{abstract}
This study aims to reveal the effects of principals' transformational leadership and teachers' competency, motivation, and discipline on the performance of the vocational high school teachers in Magelang City. This study employed a quantitative approach using the ex-post facto research design. The respondents were 89 vocational high school teachers in Magelang City. The data were collected through questionnaires. The validity was assessed by means of the Pearson's product moment correlation, while the reliability was assessed using the Cronbach's Alpha formula. The data were analyzed using the multiple linear regression technique. The results of the simple linear regression analysis indicate that the principals' transformational leadership improves the teachers' performance (sig $=p<0,05 ; R 2 y x 1=15,2 \%)$; the teachers' competency improves their performance (sig $=p<0,05$; $R 2 y \times 2=51,8 \%$ ); their motivation improves their performance (sig= $p<0,05 ; R 2 y x 3=53,9 \%$ ); and their discipline improves their performance (sig= $p<0,05 ; R 2 y x 4=45,9 \%$ ). The results of the multiple linear regression analysis show that the principals' transformational leadership and the teachers' competency, motivation, and discipline as an aggregate improves their performance (sig= $p<$ 0,05; Adjusted R2yx1,2,3,4=61,7\%).
\end{abstract}

Keywords: principals' transformational leadership, teachers' competency, teachers' motivation, teachers' discipline, teachers' performance 


\section{Pendahuluan}

Sumber daya manusia sebagai komponen penting dalam pembangunan suatu bangsa dapat ditingkatkan dengan pendidikan yang berkualitas. Menurut data United Nations Development Program (UNDP), Indek Pembangunan Manusia (IPM) Indonesia tahun 2012 di urutan 121 dari 187 negara yang disurvei, dengan skor 0,624 . Peringkat ini masih dibawah ratarata IPM negara-negara yang berada di Asia Pasifik (Annisa, 2013: 1).

Masih rendahnya kualitas sumber daya manusia tidak terlepas dari kualitas pendidikan di Indonesia yang ditentukan oleh mutu sekolah sebagai garda terdepan dalam menyelenggarakan pendidikan. Sekolah sebagai sistem memiliki dua komponen penting yang menentukan tercapainya tujuan sekolah yaitu kepala sekolah dan guru.

Kepemimpinan kepala sekolah merupakan salah satu faktor yang dapat mendorong sekolah untuk dapat mewujudkan visi, misi, tujuan dan sasaran sekolahnya melalui program-program yang dilaksanakan secara terencana dan bertahap (Mulyasa, 2011: 17).

Dalam Undang-undang Nomor 14 Tahun 2005 tentang guru dan dosen disebutkan bahwa guru adalah pendidik profesional dengan tugas utama mendidik, mengajar, membimbing, mengarahkan, melatih, menilai, dan mengevaluasi peserta didik. Guru sebagai tenaga profesional guru harus memiliki kompetensi pedagogik, kompetensi kepribadian, kompetensi sosial, dan kompetensi profesional yang diperoleh melalui pendidikan profesi. Oleh karena itu guru dituntut untuk selalu mengembangkan profesionalisme dan keterampilan dalam membangkitkan semangat belajar siswa Kompetensi guru merupakan perpaduan antara kemampuan personal, keilmuan, teknologi, sosial dan spitritual yang secara kaffah membentuk standar profesi guru (Mulyasa, 2007: 26).

Data dari Kementerian Pendidikan dan Kebudayaan menunjukkan bahwa kompetensi guru di Indonesia masih ren- dah. Pelaksanaan Uji Kompetensi Guru (UKG) yang dilaksanakan pada bulan Maret 2012 didapatkan nilai rata-rata sebesar 42, masih dibawah batas minimal yang ditetapkan yaitu 70. Kejelasan dalam mengajar, penggunaan media pembelajaran, antusianisme guru dalam mengajar, fokus pada tugas dan pemberian kesempatan pada siswa untuk belajar adalah lima hal pokok yang harus dimiliki guru dalam menjalankan tugas (Fred C.L., 2000: 485).

Guru yang memiliki motivasi tinggi dalam menjalankan tugasnya akan meningkatkan semangat kerja dan berakibat pada peningkatan produktifitas kerja. Kondisi ini akan membuat guru dan warga sekolah yang lain akan dapat bekerja dengan tepat sesuai dengan standar dan waktu yang telah ditentukan (Ishak, 2003: 16)

Dalam menjalankan tugasnya, tidak jarang ditemukan guru yang kurang memiliki gairah dalam menjalankan tugasnya sehingga tujuan sekolah yang ditetapkan sulit terwujud (Hamzah, 2008: 63). Berdasarkan studi pendahuluan di beberapa sekolah yang akan diteliti, masih terdapat guru yang kurang termotivasi dalam bekerja. Guru mengajar hanya untuk memenuhi tuntutan atau kewajibannya dalam mengajar tanpa melakukan inovasi dalam proses pembelajaran. Survei yang dilakukan balitbang harian Kompas menunjukkan mayoritas guru (70\%) masih mengandalkan materi bahan ajar yang direkomendasikan Kementerian Pendidikan dan Kebudayaan serta materi dari penerbit buku sebagai sumber informasi pengajaran (Kompas, 2013: 14).

Guru yang disiplin adalah guru yang tertib dan teratur dalam menjalankan tugasnya. Guru selalu mentaati segala aturan dan tidak melakukan pelanggaran yang merugikan dirinya, sejawatnya dan sekolah tempatnya bertugas (Ali Imron, 1995: 183). Dilihat dari sudut pandang kedisiplinan kerja, pada realitanya terdapat guru yang masih kurang disiplin, hal itu terlihat antara lain kehadiran guru ke sekolah tidak tepat waktu dan ketepatan dalam memanfaatkan waktu pembelajaran 
di kelas. Data di salah satu sekolah yang dijadikan subjek penelitian tingkat kehadiran guru adalah 95\%, tetapi ketepatan waktu kehadiran baru 70\%. Hal ini mengidentifikasikan disiplin guru belum sesuai dengan yang diharapkan.

Kinerja Guru pada dasarnya merupakan kinerja atau unjuk kerja yang dilakukan oleh guru dalam melaksanakan tugasnya sebagai pendidik. Kualitas kinerja guru akan sangat menentukan kualitas hasil pendidikan, karena guru merupakan pihak yang paling banyak bersentuhan langsung dengan siswa dalam proses pendidikan/pembelajaran di lembaga pendidikan Sekolah (Djohar, 2006: 57).

Berdasarkan studi pendahuluan yang dilakukan, masih terdapat guru SMK di Kota Magelang yang belum perangkat pembelajaran, antara lain membuat program tahunan, program semester, silabus dan rencana program pembelajaran (RPP). Data dari pengawas SMK dinas Pendidikan Kota Magelang menunjukkan bahwa sebanyak $60 \%$ guru sudah membuat RPP dengan benar, sisanya RPP yang dibuat guru kurang aplikatif untuk diterapkan dalam pembelajaran di kelas. Kondisi tersebut mengindikasikan belum optimalnya kinerja guru dalam merencanakan dan melaksanakan pembelajaran.

Kepemimpinan Kepala Sekolah Menengah Kejuruan dan kedisiplinan guru yang belum optimal, kompetensi guru yang minimal dan motivasi sebagian guru yang masih rendah dalam menjalankan tugas akan mempengaruhi kinerja guru. Berdasarkan permasalahan di atas, maka penelitian ini bertujuan untuk mengungkap pengaruh kepemimpinan transformasional kepala sekolah, kompetensi, motivasi dan kedisiplinan guru terhadap kinerja guru sekolah menengah kejuruan di kota Magelang.

Penelitian ini diharapkan dapat menambah wawasan bagi pengembangan ilmu manajemen pendidikan dan munculnya konsep-konsep kontektual yang berhubungan dengan keterkaitan kepemimpinan transformasional kepala sekolah, kompe- tensi, motivasi dan kedisiplinan guru dalam meningkatkan kinerja guru di sekolah.

Manfaat penelitian secara praktis dapat memberi masukan kepada kepala sekolah untuk meningkatkan kompetensi dan keterampilan manajerialnya dalam menjalankan kegiatan di sekolah. Bagi guru dapat memberikan masukan kepada guru untuk memunculkan motivasi internal dan disiplin pribadi dalam menjalankan tugas.

Variabel-variabel penelitian agar dapat diukur maka dijabarkan dalam definisi operasional. Dimensi yang diukur dari variabel Kepemimpinan transformasional adalah karisma, kepekaan individu, stimulus intelektual dan memberi inspirasi. Dimensi yang diukur dari variabel kompetensi guru penguasaan terhadap karakteristik peserta didik, menguasai teori belajar dan prinsip-prinsip pembelajaran, pengembangan kurikulum, kegiatan pembelajaran, Pengembangan potensi peserta didik dan Penilaian dan evaluasi. Dimensi yang diukur dari variabel motivasi guru adalah motif, harapan dan insentif. Dimensi yang diukur dari variabel kedisiplinan guru adalah ketepatan waktu, kesadaran dalam bekerja dan kepatuhan pada peraturan. Dimensi yang diukur dari variabel kinerja guru adalah kemampuan, inisiatif, ketepatan waktu, kualitas kerja dan komunikasi.

\section{Metode Penelitian}

Jenis Penelitian

Jenis penelitian ini adalah penelitian ex-post facto Desain penelitian ini menggunakan desain kuantitatif dengan metode survei yaitu metode untuk memperoleh informasi dari beberapa responden dengan menggunakan angket.

\section{Waktu dan Tempat Penelitian}

Penelitian ini dilakukan di seluruh Sekolah Mengah Kejuruan (SMK) yang terdapat di wilayah kota Magelang dan dilaksanakan pada bulan Desember 2012 sampai dengan Februari 2013. 
Subjek Penelitian

Populasi dalam penelitian ini adalah semua guru SMK yang mengajar di sekolah negeri dan swasta. Jumlah populasi sebanyak 770 orang yang mengajar di 18 SMK wilayah kota Magelang baik yang berstatus PNS maupun non PNS.

Pengambilan sampel dalam penelitian ini dilakukan dengan teknik proportional random sampling artinya jumlah guru yang dijadikan sampel diambil secara proporsional sesuai jumlah guru di setiap sekolah. Jumlah sampel sebanyak 89 guru.

\section{Teknik dan Instrumen Pengumpulan Data}

Alat pengumpulan data penelitian dilakukan dengan mengacu kepada variabel yang diteliti. Adapun variabel yang diteliti mencakup kepemimpinan transformasional kepala sekolah, kompetensi guru, motivasi guru, kedisiplinan guru dan kinerja guru. Alat ukur penelitian ini berbentuk angket, maka instrumen yang digunakan adalah angket atau kuesioner. Kuesioner adalah sejumlah pertanyaan tertulis yang digunakan untuk memperoleh informasi dari responden.

Data variabel bebas kepemimpinan transformasional kepala sekolah $\left(\mathrm{X}_{1}\right)$, kompetensi guru $\left(X_{2}\right)$, motivasi guru $\left(X_{3}\right)$, kedisiplinan guru $\left(\mathrm{X}_{4}\right)$ dan variabel terikat berupa kinerja guru $(Y)$ merupakan data ordinal yang berbentuk skala likert. Skor jawaban untuk setiap pertanyaan yang dinyatakan dengan skor 1,2,3 dan 4 atau sebaliknya $4,3,2$, 1 . Untuk pernyataan positif tanggapan dari responden mempunyai skor 1 jika sangat tidak setuju, skor 2 jika tidak setuju, skor 3 jika setuju dan skor 4 jika sangat setuju. Sebaliknya untuk pertanyaan negatif diberikan skor kebalikannya. Kuesioner yang digunakan dalam penelitian disusun melalui beberapa tahap, tahap penentuan indikator variabel berdasarkan difinisi konsep dari kajian teori, penyusunan konsep kuesioner dan uji coba kuesioner. Uji coba instrumen dilakukan kepada 30 responden secara proporsional kepada sekolah yang akan dijadikan objek penelitian.
Teknik Analisis Data

Penelitian ini menggunakan statistik sebagai alat analisis datanya. Metode statistik yaitu dengan menggunakan regresi ganda. Sebelum dilakukan uji hipotesis, terlebih dulu dilakukan uji prasyarat yaitu uji normalitas, multikolinieritas dan autokorelasi. Uji normalitas bertujuan untuk melihat normal tidaknya distribusi sebaran jawaban subyek pada suatu variabel yang dianalisis. Uji multikoloniaritas digunakan untuk menyatakan ada atau tidaknya hubungan yang sangat tinggi antara sesama variabel bebas dari model regresi. Uji Autokorelasi digunakan untuk menguji apakah dalam sebuah model regresi linier terdapat korelasi antara kesalahan pengganggu pada periode $t$ dengan kesalahan pada periode $\mathrm{t}-1$ (sebelumnya). Untuk menguji autokorelasi dapat dilihat dari nilai Durbin Waston (DW), yaitu jika nilai DW terletak antara du dan $(4-\mathrm{dU})$ atau du $\leq \mathrm{DW} \leq(4-\mathrm{dU})$, berarti bebas dari autokorelasi.

Analisis deskriptif variabel dilakukan dengan cara menghitung dan menyajikan karakteristik kuantitatif tiap variabel yakni ukuran tendensi sentral (rata-rata, median), ukuran dispersi (nilai maksimum, nilai minimum, jangkauan, standar deviasi).

Uji hipotesis menggunakan Uji signifikan regresi berganda. Uji ini dilakukan untuk mengetahui seberapa besar variasi dari variabel indpenden. $\mathrm{R}$ menunjukkan hubungan antara variabel yang besarnya koefesien berkisar antara 0 dan 1 . Nilai $R^{2}$ yang kecil berarti kemampuan variabelvariabel independen dalam menjelaskan variasi dependen amat terbatas.

Koefisien determinan $\left(\mathrm{R}^{2}\right)$ digunakan untuk mengetahui pengaruh variabel variabel bebas terhadap variabel terikat. Uji F digunakan untuk mengetahui apakah variabel independen secara serentak atau bersama-sama berpengaruh terhadap variabel dependen. 


\section{Hasil Penelitian dan Pembahasan}

Deskripsi Data

Deskripsi data penelitian bertujuan untuk mengetahui gambaran karakteristik masing-masing variabel penelitian. Analisis deskripsi variabel dilakukan dengan cara statistik deskriptif yaitu menghitung dan menyajikan data kuantitatif tiap-tiap variabel yang terdiri dari rata-rata (mean), nilai tengah (median), nilai yang sering muncul (mode) simpangan baku (standar deviasi), rentang (range), nilai maksimum, nilai minimum dan jumlah.

Deskripsi Data Variabel Kepemimpinan Transformasional Kepala Sekolah

Berdasarkan data yang berasal dari 89 responden, diperoleh beberapa deskripsi kuantitatif variabel kepemimpinan transformasional kepala sekolah.

Tabel 1. Analisis Statistik Deskripsi Kepemimpinan Transformasional Kepala Sekolah

\begin{tabular}{lr}
\hline \multicolumn{1}{c}{ Deskripsi Data } & \multicolumn{2}{c}{ Nilai } \\
\hline Rata-rata & 66,64 \\
Nilai tengah & 66,00 \\
Modus & 61,00 \\
Standar deviasi & 6,741 \\
Variasi & 45,437 \\
Jangkauan & 37 \\
Nilai minimum & 44 \\
Nilai maksimum & 81 \\
\hline Jumlah & 5931 \\
\hline
\end{tabular}

Dari tabel 1 diperoleh rata-rata skor 66,64; median 66,00; nilai minimum 44; nilai maksimum 81 sehingga jangkauan 37 dan standar deviasi 6,741. Distribusi frekuensi dan histogram variabel kepemimpinan transformasi-onal kepala sekolah digambarkan dalam tabel 2 dan gambar 1 .
Tabel 2. Distribusi Frekuensi

Kepemimpinan Transformasional Kepala Sekolah

\begin{tabular}{|c|c|c|c|c|}
\hline $\begin{array}{l}\text { Rentang } \\
\text { skor }\end{array}$ & Frequency & Percent & $\begin{array}{c}\text { Valid } \\
\text { Percent }\end{array}$ & $\begin{array}{c}\text { Cumulative } \\
\text { Percent }\end{array}$ \\
\hline $44-49$ & 1 & 1,1 & 1,1 & 1,1 \\
\hline $56-61$ & 24 & 27,0 & 27,0 & 28,1 \\
\hline $62-67$ & 27 & 30,3 & 30,3 & 58,4 \\
\hline $68-73$ & 18 & 20,2 & 20,2 & 78,7 \\
\hline $74-79$ & 18 & 20,2 & 20,2 & 98,9 \\
\hline $80-85$ & 1 & 1,1 & 1,1 & 100,0 \\
\hline Total & 89 & 100,0 & 100,0 & \\
\hline
\end{tabular}

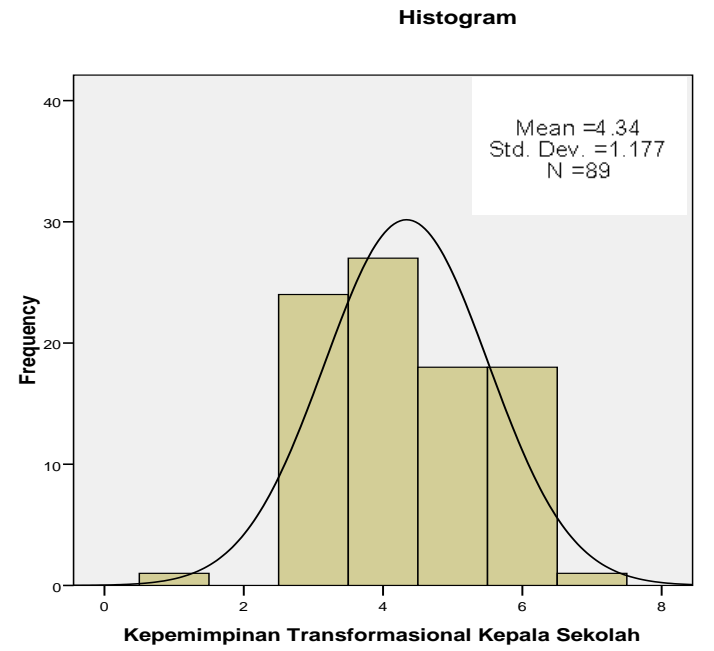

Gambar 1. Histogram Variabel Kepemimpinan Transformasional Kepala Sekolah

\section{Deskripsi Data Variabel Kompetensi Guru}

Berdasarkan data yang berasal dari 89 responden, diperoleh beberapa deskripsi kuantitatif variabel kompetensi guru.

Pada tabel 3 diperoleh rata-rata skor 70,74; median 70,00; nilai minimum 53; nilai maksimum 87 sehingga jangkauan 34 dan standar deviasi 6,473. Distribusi frekuensi dan histogram variabel kompetensi guru digambarkan dalam Tabel 4 dan Gambar 2. 
Tabel 3. Analisis Statistik Deskripsi Kompetensi Guru

\begin{tabular}{lr}
\hline \multicolumn{1}{c}{ Deskripsi Data } & \multicolumn{1}{c}{ Nilai } \\
\hline Rata-rata & 70,74 \\
Nilai tengah & 70,00 \\
Modus & 71 \\
Standar deviasi & 6,473 \\
Variasi & 41,898 \\
Jangkauan & 34 \\
Nilai minimum & 53 \\
Nilai maksimum & 87 \\
\hline Jumlah & 6296 \\
\hline
\end{tabular}

Tabel 4. Distribusi Frekuensi Variabel Kompetensi Guru

\begin{tabular}{ccccc}
\hline $\begin{array}{c}\text { Rentang Frequency } \\
\text { skor }\end{array}$ & & $\begin{array}{c}\text { Vercentid } \\
\text { Percent }\end{array}$ & $\begin{array}{c}\text { Cumulative } \\
\text { Percent }\end{array}$ \\
\hline $53-57$ & 1 & 1,1 & 1,1 & 1,1 \\
$58-62$ & 5 & 5,6 & 5,6 & 6,7 \\
$63-67$ & 24 & 27,0 & 27,0 & 33,7 \\
$68-72$ & 31 & 34,8 & 34,8 & 68,5 \\
$73-77$ & 13 & 14,6 & 14,6 & 83,1 \\
$78-82$ & 11 & 12,4 & 12,4 & 95,5 \\
$83-87$ & 4 & 4,5 & 4,5 & 100,0 \\
\hline Total & 89 & 100,0 & 100,0 & \\
\hline
\end{tabular}

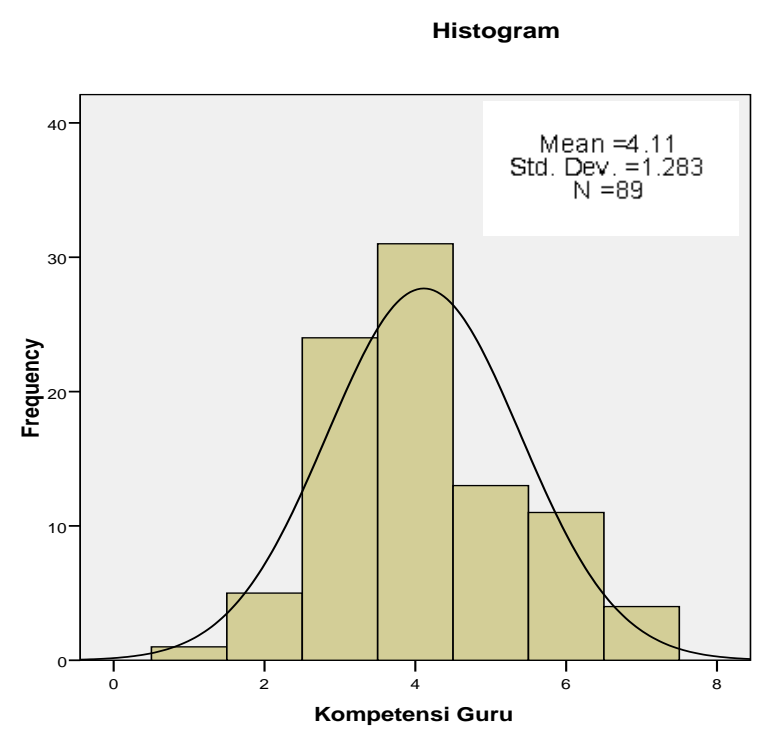

Gambar 2. Histogram Variabel Kompetensi
Deskripsi Data Variabel Motivasi Guru

Berdasarkan data yang berasal dari 89 responden, diperoleh beberapa deskripsi kuantitatif variabel motivasi guru.

Tabel 5. Analisis Statistik Deskripsi Motivasi Guru

\begin{tabular}{lr}
\hline \multicolumn{1}{c}{ Deskripsi Data } & \multicolumn{2}{c}{ Nilai } \\
\hline Rata-rata & 61,60 \\
Nilai tengah & 61,00 \\
Modus & 58 \\
Standar deviasi & 5,801 \\
Variasi & 33,653 \\
Jangkauan & 29 \\
Nilai minimum & 48 \\
Nilai maksimum & 77 \\
\hline Jumlah & 5482 \\
\hline
\end{tabular}

Dari tabel 5 diperoleh rata-rata skor 61,60; median 61,00; nilai minimum 48; nilai maksimum 77 sehingga jangkauan 29 dan standar deviasi 5,801. Distribusi frekuensi dan histogram variabel motivasi guru digambarkan dalam tabel 6 dan gambar 3.

Tabel 6. Distribusi Frekuensi Variabel Motivasi Guru

\begin{tabular}{ccccc}
\hline $\begin{array}{c}\text { Rentang } \\
\text { skor }\end{array}$ & Frequency & Percent & $\begin{array}{c}\text { Valid } \\
\text { Percent }\end{array}$ & $\begin{array}{c}\text { Cumulative } \\
\text { Percent }\end{array}$ \\
\hline $48-52$ & 2 & 2.2 & 2,2 & 2,2 \\
$53-57$ & 20 & 22,5 & 22,5 & 24,7 \\
$58-62$ & 30 & 33,7 & 33,7 & 58,4 \\
$63-67$ & 26 & 29,2 & 29,2 & 87,6 \\
$68-72$ & 6 & 6,7 & 6,7 & 94,4 \\
$73-77$ & 5 & 5,6 & 5,6 & 100,0 \\
\hline Total & 89 & 100,0 & 100,0 & \\
\hline
\end{tabular}




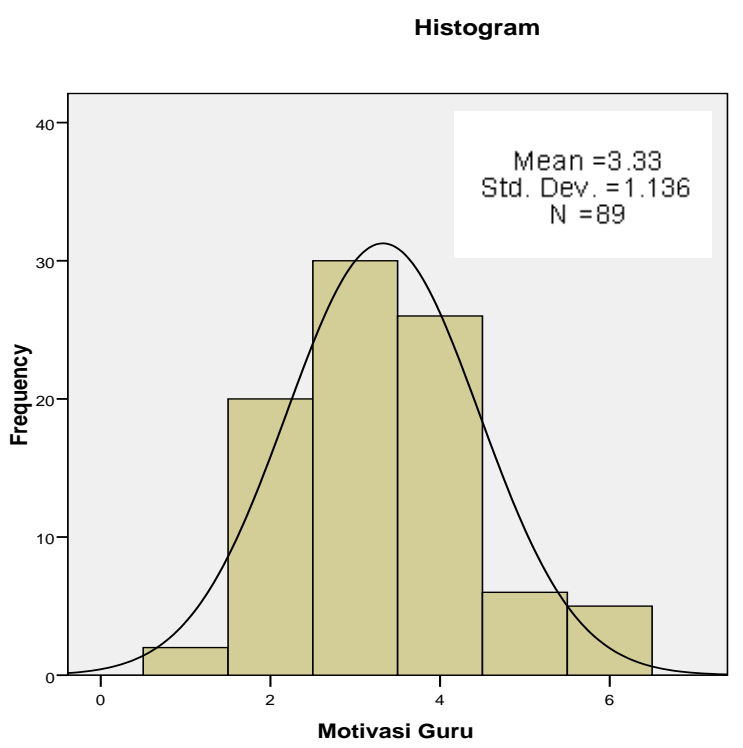

Gambar 3. Histogram Variabel Motivasi Guru

Deskripsi Data Variabel Kedisiplinan Guru

Berdasarkan data yang berasal dari 89 responden, diperoleh beberapa deskripsi kuantitatif variabel kedisiplinan guru.

Tabel 7. Analisis Statistik Deskripsi Kedisiplinan Guru

\begin{tabular}{lr}
\hline \multicolumn{1}{c}{ Deskripsi Data } & \multicolumn{1}{c}{ Nilai } \\
\hline Rata-rata & 69,55 \\
Nilai tengah & 69,00 \\
Modus & 63 \\
Standar deviasi & 7,641 \\
Variasi & 58,387 \\
Jangkauan & 30 \\
Nilai minimum & 54 \\
Nilai maksimum & 84 \\
\hline Jumlah & 6190 \\
\hline
\end{tabular}

Dari tabel 7 diperoleh rata-rata skor 69,55; median 69,00; nilai minimum 54; nilai maksimum 84 sehingga jangkauan 30 dan standar deviasi 7,641. Distribusi frekuensi dan histogram variabel kedisiplinan guru digambarkan dalam Tabel 8 dan Gambar 4.
Tabel 8. Distribusi Frekuensi Variabel Kedisiplinan Guru

\begin{tabular}{ccccc}
\hline $\begin{array}{c}\text { Rentang } \\
\text { skor }\end{array}$ & Frequency & Percent & $\begin{array}{c}\text { Valid } \\
\text { Percent }\end{array}$ & $\begin{array}{c}\text { Cumulative } \\
\text { Percent }\end{array}$ \\
\hline $53-57$ & 3 & 3,4 & 3,4 & 3,4 \\
$58-62$ & 27 & 30,3 & 30,3 & 33,7 \\
$63-67$ & 13 & 14,6 & 14,6 & 48,3 \\
$68-72$ & 21 & 23,6 & 23,6 & 71,9 \\
$73-77$ & 11 & 12,4 & 12,4 & 84,3 \\
$78-82$ & 12 & 13,5 & 13,5 & 97,8 \\
$83-87$ & 2 & 2,2 & 2,2 & 100.0 \\
\hline Total & 89 & 100,0 & 100,0 \\
\hline \multicolumn{5}{c}{ Histogram }
\end{tabular}

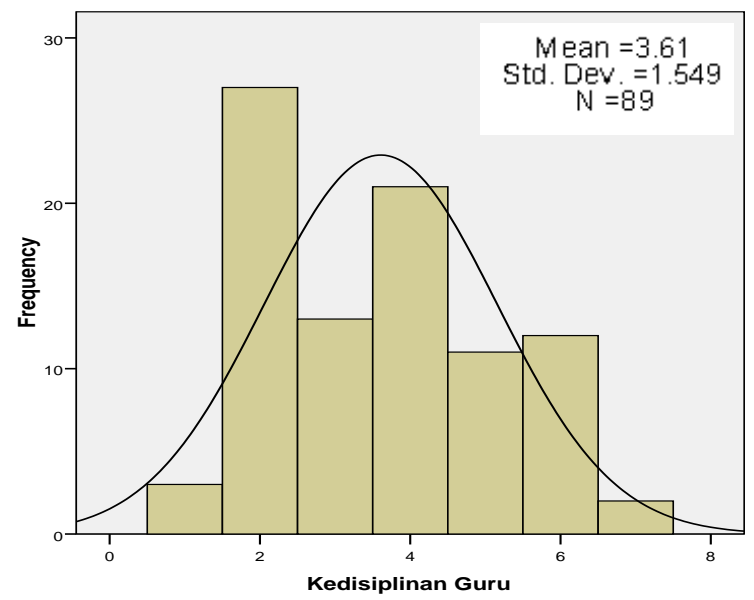

Gambar 4. Histogram Variabel Kedisiplinan Guru

Deskripsi Data Variabel Kinerja Guru

Berdasarkan data yang berasal dari 89 responden, diperoleh beberapa deskripsi kuantitatif variabel kinerja guru.

Tabel 9. Analisis Statistik Deskripsi Kinerja Guru

\begin{tabular}{lr}
\hline \multicolumn{1}{c}{ Deskripsi Data } & \multicolumn{1}{c}{ Nilai } \\
\hline Rata-rata & 66,36 \\
Nilai tengah & 65,00 \\
Modus & 63 \\
Standar deviasi & 6,509 \\
Variasi & 42,369 \\
Jangkauan & 28 \\
Nilai minimum & 54 \\
Nilai maksimum & 82 \\
\hline Jumlah & 5906 \\
\hline
\end{tabular}


Dari tabel 9 diperoleh rata-rata skor 66,36; median 65,00; nilai minimum 54; nilai maksimum 82 sehingga jangkauan 28 dan standar deviasi 6,509. Distribusi frekuensi dan histogram variabel kedisiplinan guru digambarkan dalam Tabel 10 dan Gambar 5.

Tabel 10. Distribusi Frekuensi Variabel Kinerja Guru

\begin{tabular}{ccccc}
\hline $\begin{array}{c}\text { Rentan } \\
\text { g skor }\end{array}$ & $\begin{array}{c}\text { Frequen } \\
\text { cy }\end{array}$ & $\begin{array}{c}\text { Percen } \\
\mathrm{t}\end{array}$ & $\begin{array}{c}\text { Valid } \\
\text { Percen } \\
\mathrm{t}\end{array}$ & $\begin{array}{c}\text { Cumul } \\
\text { a tive } \\
\text { Percen } \\
\mathrm{t}\end{array}$ \\
$53-57$ & 4 & 4,5 & 4,5 & 4,5 \\
$58-62$ & 21 & 23,6 & 23,6 & 28,1 \\
$63-67$ & 22 & 24,7 & 24,7 & 52,8 \\
$68-72$ & 15 & 16,9 & 16,9 & 69,7 \\
$73-77$ & 10 & 11,2 & 11,2 & 80,9 \\
$78-82$ & 11 & 12,4 & 12,4 & 93,3 \\
$83-87$ & 6 & 6,7 & 6,7 & 100,0 \\
Total & 89 & 100,0 & 100,0 & \\
\hline
\end{tabular}

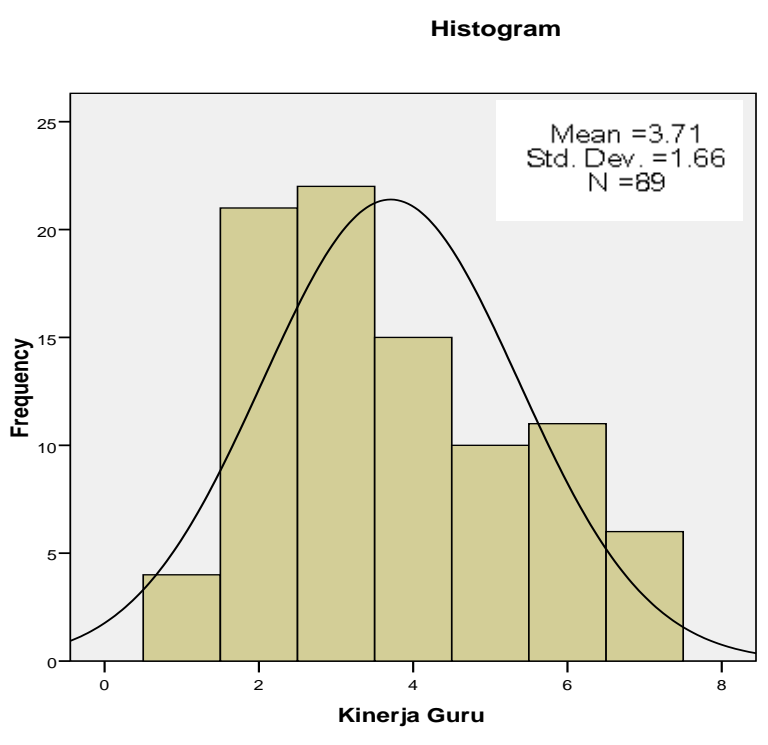

Gambar 5. Histogram Variabel Kinerja Guru

Hasil Uji Hipotesis

Analisis pengaruh kepemimpinan transformasional kepala sekolah terhadap kinerja guru.
Tabel 11. Nilai R Square Variabel Kepemimpinan Transformasional Kepala Sekolah Model Summary

Model R R Square Adjusted Std. Error of R Square The Estimate

\begin{tabular}{|c|c|c|c|c|}
\hline 1 & 389a & .152 & .142 & 6.030 \\
\hline
\end{tabular}

Angka R square atau koefisien determinasi adalah 0,152. Hal ini berarti $15,2 \%$ variasi dari kinerja guru dijelaskan oleh variabel kepemimpinan transformasional kepala sekolah, sedangkan sisanya $84,8 \%$ dijelaskan oleh sebab-sebab lain.

Tabel 12. Harga Signifikansi Pengaruh Kepemimpinan

Transformasional Kepala Sekolah terhadap Kinerja Guru

\begin{tabular}{llllll}
\multicolumn{6}{c}{ ANOVA $^{\mathrm{b}}$} \\
\hline Model & $\begin{array}{l}\text { Sum of } \\
\text { Squares }\end{array}$ & df & $\begin{array}{l}\text { Mean } \\
\text { Square }\end{array}$ & F & Sig. \\
\hline 1 & 565.345 & 1 & 565.345 & 15.549 & $.000^{\mathrm{a}}$ \\
Regression & & & & &
\end{tabular}

\begin{tabular}{rrrr} 
Residual & 3163.149 & 87 & 36.358 \\
\hline Total & 3728.494 & 88 & \\
\hline
\end{tabular}

aPredictors: (Constant), Kepemimpinan Transformasional Kepala Sekolah Dependent Variable: Kinerja Guru

Dari tabel 12 dapat dilihat bahwa harga sig $(p)$ adalah $0,000^{a}<0,05$, yang berarti kepemimpinan transformasional kepala sekolah berpengaruh signifikan terhadap kinerja guru.

Tabel 13. Harga $\beta$ dan Koefisien Regresi Pengaruh Kepemimpinan Transformasional Kepala Sekolah terhadap Kinerja Guru Coefficients ${ }^{\text {a }}$

\begin{tabular}{|c|c|c|c|c|c|}
\hline \multirow[b]{2}{*}{ Model } & \multicolumn{2}{|c|}{$\begin{array}{l}\text { Unstandar- } \\
\text { dized } \\
\text { Coefficients }\end{array}$} & \multirow{2}{*}{$\frac{\begin{array}{c}\text { Standar-dized } \\
\text { Coefficients }\end{array}}{\text { Beta }}$} & \multirow{2}{*}{ 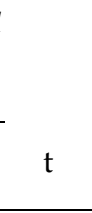 } & \multirow[t]{2}{*}{ Sig. } \\
\hline & B & $\begin{array}{c}\text { Std } \\
\text { Error }\end{array}$ & & & \\
\hline 1 (Constant) & 41.302 & 6.387 & & 6.467 & $.000 \mathrm{a}$ \\
\hline $\begin{array}{l}\text { Kepemimpin } \\
\text { an Transfor- } \\
\text { masional Ke- } \\
\text { pala Sekolah }\end{array}$ & .376 & .095 & .389 & 3.943 & \\
\hline
\end{tabular}


Dari analisis uji F, dapat diprediksi besarnya nilai variabel kinerja guru melalui persamaan regresi : $\mathrm{Y}=41,302+0,389 \mathrm{X}_{1}$ Angka 41,302 menyatakan apabila tidak ada pengaruh dari variabel kepemimpinan transformasional kepala sekolah $\left(X_{1}\right)$ pada dasarnya variabel kinerja guru (Y) sudah memiliki nilai sebesar 41,302. Angka koefisien regresi 0,389 menjelaskan setiap penambahan satu nilai variabel $X_{1}$ akan meningkatkan variabel kinerja guru sebesar 0,389.

Kepemimpinan transformasional kepala sekolah yang bercirikan antara lain sebagai agen perubahan, memiliki visi kedepan, mengutamakan partisipasi guru, dan memberdayakan semua potensi yang ada di sekolah ternyata memberikan sumbangan kepada kinerja guru sebesar $15,2 \%$. Kemampuan kepala sekolah dalam menerjemahkan visi, misi dan tujuan sekolah dalam melaksanakan tugas kepemimpinannya memotivasi guru untuk meningkatkan kinerjanya. Guru menjadi lebih kreatif dan produktif dalam menjalankan tugas dan fungsinya untuk mencapai tujuan sekolah yang telah ditetapkan bersama. Hal ini sesuai dengan pendapat Burns yang menjelaskan bahwa kepemimpinan transformasional dapat meningkatkan moralitas dan motivasi yang lebih tinggi dalam mencapai tujuan organisasi. Pendapat lain menurut Yukl kepemimpinan transformasional dapat meningkatkan komitmen, motivasi dan kepercayaan bawahan sehingga menempatkan tujuan organisasi di atas kepentingan pribadinya (Yukl, 2009: 304). Guru sebagai salah satu komponen dalam pendidikan di sekolah akan meningkat kinerjanya jika berada dalam semangat dan motivasi yang tinggi.

Analisis pengaruh kompetensi guru terhadap kinerja guru

Tabel 14. Nilai R Square Variabel

Kompetensi Guru

Model Summary

\begin{tabular}{ccccc}
\hline Model & $R$ & $R$ Square Adjusted $R$ & $\begin{array}{c}\text { Std. Error of } \\
\text { Square }\end{array}$ & $\begin{array}{c}\text { The Estimate } \\
\text { The }\end{array}$ \\
\hline 1 & $720^{\mathrm{a}}$ & .518 & .513 & 4.544 \\
\hline a Predictors: (Constant), Kompetensi Guru
\end{tabular}

Angka $\mathrm{R}$ square atau koefisien determinasi adalah 0,518. Hal ini berarti $51,8 \%$ variasi dari kinerja guru dijelaskan oleh kompetensi guru, sedangkan sisanya $48,2 \%$ dijelaskan oleh sebab-sebab lain.

Tabel 15. Harga Signifikansi

Pengaruh Kompetensi Guru terhadap Kinerja Guru ANOVA $^{\text {b }}$

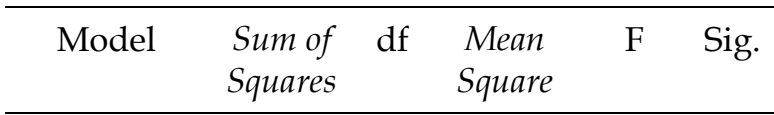

1 Regression $1932.436 \quad 1 \quad 1932.43693 .606$.000a

Residual $\quad 1796.058 \quad 87 \quad 20.644$

Total $\quad 3728.494 \quad 88$

a Predictors: (Constant), Kompetensi Guru

Dependent Variable: Kinerja Guru

Dari tabel 15 dapat dilihat bahwa harga sig $(p)$ adalah 0,000a $<0,05$, yang berarti kompetensi guru berpengaruh signifikan terhadap kinerja guru.

Tabel 16. Harga $\beta$ dan Koefisien

Regresi Pengaruh Kompetensi Guru terhadap Kinerja Guru Coefficients a

\begin{tabular}{|c|c|c|c|c|c|}
\hline \multirow[t]{2}{*}{ Model } & \multicolumn{2}{|c|}{$\begin{array}{c}\text { Unstandar- } \\
\text { dized } \\
\text { Coefficients }\end{array}$} & \multirow{2}{*}{$\begin{array}{c}\begin{array}{c}\text { Standar- } \\
\text { dized } \\
\text { Coefficients }\end{array} \\
\text { Beta }\end{array}$} & \multirow[t]{2}{*}{$t$} & \multirow[t]{2}{*}{ Sig. } \\
\hline & B & $\begin{array}{l}\text { Std } \\
\text { Error }\end{array}$ & & & \\
\hline 1 (Constant) & 15.14 & 5.315 & & 2.849 & .005 \\
\hline $\begin{array}{l}\text { Kompetensi } \\
\text { Guru }\end{array}$ & .724 & .075 & .720 & 9.675 & .000 \\
\hline
\end{tabular}

Dependent Variable: Kinerja Guru

Dari analisis uji F, dapat diprediksi besarnya nilai variabel kinerja guru melalui persamaan regresi : $\mathrm{Y}=15,146+0,720 \mathrm{X}_{2}$

Angka 15,146 menyatakan apabila tidak ada pengaruh dari variabel kompetensi guru $\left(\mathrm{X}_{2}\right)$ pada dasarnya variabel kinerja guru (Y) sudah memiliki nilai sebesar 15,146. Angka koefisien regresi 0,720 menjelaskan setiap penambahan satu nilai variabel $\mathrm{X}_{2}$ akan meningkatkan variabel kinerja guru sebesar 0,720 .

Kompetensi guru yang meliputi kompetensi pedagogik, kompetensi kepribadian, kompetensi profesional, dan kompetensi sosial memberikan sumbangan ter- 
hadap kinerja guru sebesar 51,8\%. Kompetensi guru yang merupakan kebulatan dari pengetahuan, ketrampilan dan sikap menunjukkan pengaruh yang signifikan terhadap kinerja guru. Kompetensi pedagogik yang meliputi kegiatan pengelolaan pembelajaran dari perencanaan, pelaksanaan dan pengendalian proses pembelajaran akan berdampak kepada kemampuan peserta didik dalam menyerap pengetahuan yang disampaikan guru. Salah satu indikator yang dapat diamati dari peningkatan kinerja guru adalah meningkatnya hasil belajar siswa dan perubahan sikap siswa menjadi lebih baik.

Kemampuan akan menentukan seseorang dalam melakukan pekerjaan yang berakibat pada peningkatan kinerja. Hal tersebut sama dengan pendapat Mulyasa, bahwa penguasaan kompetensi pedagogik disertai dengan profesional akan menentukan tingkat keberhasilan proses dan hasil pembelajaran peserta didik.

Analisis pengaruh motivasi guru terhadap kinerja guru

Tabel 17. Nilai R Square Variabel Motivasi Guru Model Summary

\begin{tabular}{ccccc}
\hline Model & $\mathrm{R}$ & R Square Adjusted $R$ & $\begin{array}{c}\text { Std. Error of } \\
\text { Square } \\
\text { The Estimate }\end{array}$ \\
1 & $734^{\mathrm{a}}$ & .539 & .534 & 4.444 \\
\hline
\end{tabular}

a Predictors: (Constant), Motivasi Guru

Angka R square atau koefisien determinasi adalah 0,539. Hal ini berarti $53,9 \%$ variasi dari kinerja guru dijelaskan oleh motivasi guru, sedangkan sisanya $46,1 \%$ dijelaskan oleh sebab-sebab lain.

Tabel 18. Harga Signifikansi

Pengaruh Motivasi Guru terhadap Kinerja Guru ANOVA $^{b}$

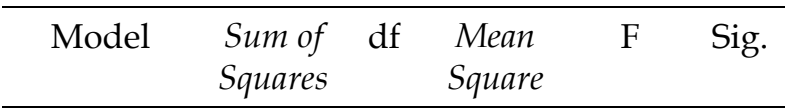

1 Regression $2010.282 \quad 1 \quad 2010.282101 .789 .000^{a}$

Residual $\quad 1718.212 \quad 87 \quad 19.750$

Total $\quad 3728.494 \quad 88$

a Predictors: (Constant), Motivasi Guru

Dependent Variable: Kinerja Guru
Dari tabel 18. dapat dilihat bahwa harga sig $(p)$ adalah $0,000^{a}<0,05$, yang berarti motivasi guru berpengaruh signifikan terhadap kinerja guru

Tabel 19. Harga $\beta$ dan Koefisien

Regresi Pengaruh Motivasi Guru terhadap Kinerja Guru

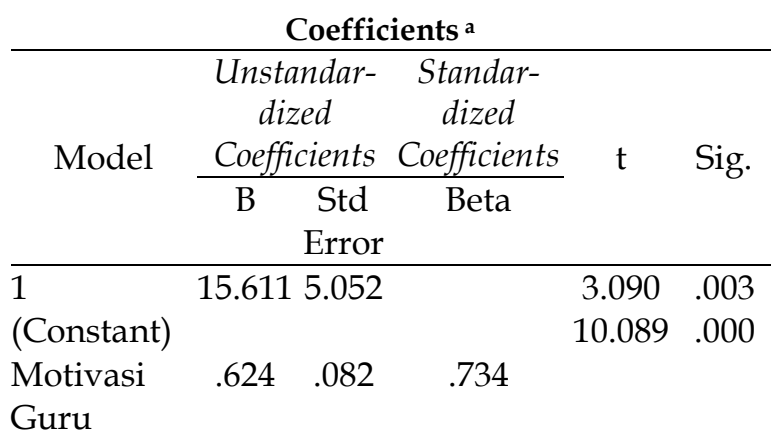

Dependent Variable: Kinerja Guru

Dari analisis uji $\mathrm{F}$, dapat diprediksi besarnya nilai variabel kinerja guru melalui persamaan regresi: $\mathrm{Y}=15,611+0,734 \mathrm{X}_{3}$ Angka 15,611 menyatakan apabila tidak ada pengaruh dari variabel motivasi guru $\left(X_{3}\right)$ pada dasarnya variabel kinerja guru (Y) sudah memiliki nilai sebesar 15,611. Angka koefisien regresi 0,734 menjelaskan setiap penambahan satu nilai variabel $X_{3}$ akan meningkatkan variabel kinerja guru sebesar 0,734.

Motivasi guru memberikan sumbangan terbesar terhadap kinerja guru yaitu 53,9\%. Hal ini menunjukkan bahwa guru akan memiliki kinerja yang baik apabila ada motivasi kuat yang terdapat dalam dirinya. Motivasi internal dan eksternal yang dimiliki, membuat guru berusaha untuk bekerja maksimal dalam melaksanakan tugasnya.

Hasil ini sesuai dengan pendapat Mc Clelland tentang Achievement Theory bahwa manusia memenuhi memiliki dorongan untuk berprestasi dalam melakukan kerja. Menurut Herzberg ada dua jenis faktor yang mendorong seseorang untuk berusaha mencapai kepuasan dan menjauhkan diri dari ketidakpuasan. Motivasi yang tinggi baik motivasi internal maupun eksternal berpengaruh pada peningkatan prestasi kerja. 
Analisis pengaruh kedisiplinan guru terhadap kinerja guru

Tabel 20. Nilai R Square Variabel Kedisiplinan Guru

\begin{tabular}{ccrrr}
\multicolumn{5}{c}{ Model Summary } \\
\hline $\begin{array}{c}\text { Mode } \\
1\end{array}$ & $\mathrm{R}$ & $\mathrm{R}$ & \multicolumn{1}{c}{ Adjusted } & Std. Error of \\
& & Square & $R$ Square & The Estimate \\
1 & $678 \mathrm{a}$ & .459 & .453 & 4.814 \\
\hline
\end{tabular}

a Predictors: (Constant), Kedisiplinan Guru

Angka R square atau koefisien determinasi adalah 0,459. Hal ini berarti $45,9 \%$ variasi dari kinerja guru dijelaskan oleh disiplin guru, sedangkan sisanya $54,1 \%$ dijelaskan oleh sebab-sebab lain.

Tabel 21. Harga Signifikansi

Pengaruh Kedisiplinan Guru terhadap Kinerja Guru

\begin{tabular}{cccccc} 
ANOvA & \\
\hline Model & $\begin{array}{c}\text { Sum of } \\
\text { Squares }\end{array}$ & df & $\begin{array}{c}\text { Mean } \\
\text { Square }\end{array}$ & F & Sig. \\
\hline 1 Regression & 1712.609 & 1 & 1712.609 & 73.911 & $.000^{\mathrm{a}}$ \\
Residual & 2015.886 & 87 & 23.171 & & \\
Total & 3728.494 & 88 & & \\
\hline a Predictors: (Constant), Kedisiplinan Guru & \\
Dependent Variable: Kinerja Guru &
\end{tabular}

Dari tabel 21 dapat dilihat bahwa harga sig $(p)$ adalah $0,000^{a}<0,05$, yang berarti kedisiplinan guru berpengaruh signifikan terhadap kinerja guru.

Tabel 22. Harga $\beta$ dan Koefisien

Regresi Pengaruh Kedisiplinan Guru terhadap Kinerja Guru

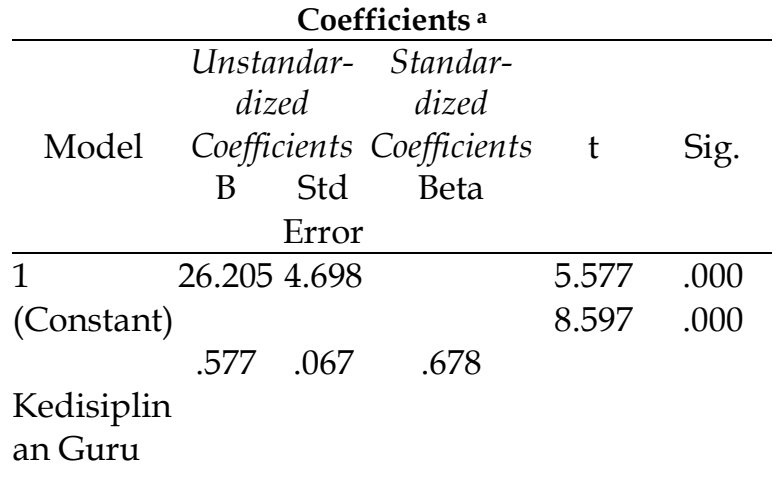

Dependent Variable: Kinerja Guru
Dari analisis uji F, dapat diprediksi besarnya nilai variabel kinerja guru melalui persamaan regresi : $\mathrm{Y}=26,205+0,678 \mathrm{X}_{4}$. Angka 26,205 menyatakan apabila tidak ada pengaruh dari variabel kedisiplinan guru $\left(X_{4}\right)$ pada dasarnya variabel kinerja guru (Y) sudah memiliki nilai sebesar 26,205. Angka koefisien regresi 0,678 menjelaskan setiap penambahan satu nilai variabel $\mathrm{X}_{4}$ akan meningkatkan variabel kinerja guru sebesar 0,678.

Kedisiplinan guru memberikan sumbangan $45,9 \%$ terhadap kinerja guru. Guru yang disiplin akan berusaha mentaati segala peraturan dan melaksanakan pembelajaran sesuai tugas pokok dan fungsinya. Disiplin pribadi dan aturan yang jelas dan tegas di sekolah membuat guru bekerja lebih optimal. Kedisiplinan guru yang baik akan meningkatkan kinerja guru dalam melaksanakan tugasnya. Hasil ini sesuai dengan pendapat Davis, bahwa seseorang melaksanakan tugasnya secara berkualitas sebagai tanggung jawab pribadi bukan karena perintah pimpinan. Pendapat yang sama disampaikan oleh Anwar, bahwa disiplin akan membuat perubahan perilaku yang lebih baik dan bertanggung jawab terhadap tugas yang diberikan.

Analisis pengaruh kepemimpinan transformasional kepala sekolah, kompetensi, motivasi dan kedisiplinan guru terhadap kinerja guru

Tabel 23. Nilai Adjusted R Square Variabel Kepemimpinan Transformasional Kepala Sekolah, Kompetensi, Motivasi dan Kedisiplinan Guru

\begin{tabular}{|c|c|c|c|c|}
\hline \multicolumn{5}{|c|}{ Model Summary } \\
\hline Model & $\mathrm{R}$ & R Square & $\begin{array}{c}\text { Adjusted } R \\
\text { Square }\end{array}$ & $\begin{array}{l}\text { Std. Error of } \\
\text { The Estimate }\end{array}$ \\
\hline 1 & $796^{\mathrm{a}}$ & .634 & .617 & 4.030 \\
\hline
\end{tabular}

Angka Adjusted $R$ square atau koefisien determinasi adalah 0,617 . Hal ini berarti $61,7 \%$ variasi dari kinerja guru dijelaskan oleh kepemimpinan transfor- 
masional kepala sekolah, kompetensi guru, motivasi guru dan kedisiplinan guru secara bersama-sama, sedangkan sisanya 38,3\% dijelaskan oleh sebab-sebab lain.

\section{Tabel 24. Harga Signifikansi}

Pengaruh Kepemimpinan

Transformasional Kepala Sekolah,

Kompetensi, Motivasi dan Kedisiplinan Guru terhadap Kinerja Guru

\begin{tabular}{cccccc}
\multicolumn{6}{c}{ ANOVA $^{\mathrm{b}}$} \\
\hline Model & $\begin{array}{c}\text { Sum of } \\
\text { Squares }\end{array}$ & $\mathrm{df}$ & $\begin{array}{c}\text { Mean } \\
\text { Square }\end{array}$ & F & Sig. \\
\hline 1 Regression 2364.476 & 4 & 591.119 & 36.403 & $.000^{\mathrm{a}}$ \\
Residual & 1364.019 & 84 & 16.238 & & \\
Total & 3728.494 & 88 & & & \\
\hline
\end{tabular}

a Predictors: (Constant), Kedisiplinan Guru, Kepemimpinan Trans formasional Kepala Sekolah, Motivasi Guru, Kedisiplinan Guru Dependent Variable: Kinerja Guru

Dari tabel 24 dapat dilihat bahwa harga sig $(p)$ adalah $0,000^{a}<0,05$. Hal ini berarti variabel kepemimpinan transformasional kepala sekolah, kompetensi guru, motivasi guru dan kedisiplinan guru secara bersama-sama memberikan pengaruh signifikan terhadap kinerja guru

Tabel 25. Harga $\beta$ dan Koefisien

Regresi Pengaruh Kepemimpinan

Transformasional Kepala Sekolah,

Kompetensi, Motivasi dan Kedisiplinan Guru terhadap Kinerja Guru

Coefficients(a)

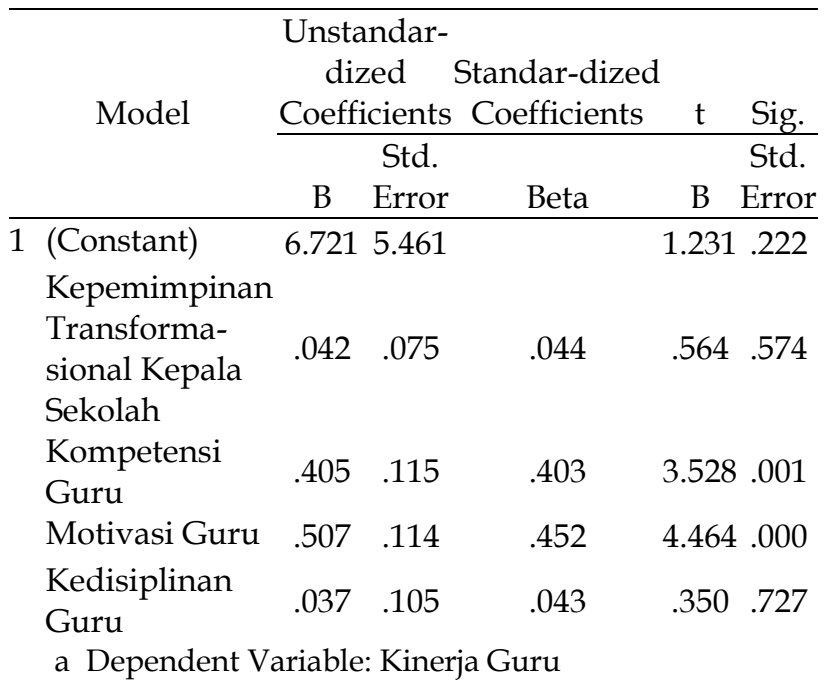

Dari analisis uji $\mathrm{F}$, dapat diprediksi besarnya nilai variabel terikat kinerja guru dapat dituliskan dengan persamaan: $\bar{Y}=6,721+0,044 X_{1}+0,403 X_{2}+0,452 X_{3}+$ $0,043 \mathrm{X}_{4}$

Angka konstanta 6,721 menyatakan apabila tidak ada pengaruh variabel $X_{1}, X_{2}$ $X_{3}$ dan $X_{4}$ secara bersama-sama pada dasarnya $\mathrm{Y}$ sudah memiliki nilai sebesar 6,721 . Angka koefisien regresi terhadap variabel kepemimpinan kepala sekolah $\left(X_{1}\right)$ adalah 0,044, menjelaskan bahwa penambahan satu nilai variabel $X_{1}$ akan meningkatkan kinerja guru sebesar 0,044 kali dengan asumsi $X_{2}, X_{3}$ dan $X_{4}$ tetap. Angka koefisien regresi terhadap variabel kompetensi guru $\left(X_{2}\right)$ adalah 0,403 , menjelaskan bahwa penambahan satu nilai variabel $X_{2}$ akan meningkatkan kinerja guru sebesar 0,403 kali dengan asumsi $X_{1}, X_{3}$ dan $X_{4}$ tetap. Angka koefisien regresi terhadap variabel motivasi guru $\left(X_{3}\right)$ adalah 0,452 , menjelaskan bahwa penambahan satu nilai variabel $\mathrm{X}_{3}$ akan meningkatkan kinerja guru sebesar 0,452 kali dengan asumsi $X_{1}$, $\mathrm{X}_{2}$ dan $\mathrm{X}_{4}$ tetap. Angka koefisien regresi terhadap variabel disiplin guru $\left(X_{4}\right)$ adalah 0,043, menjelaskan bahwa penambahan satu nilai variabel $\mathrm{X}_{4}$ akan meningkatkan kinerja guru sebesar 0,043 kali dengan asumsi $X_{1}, X_{2}$ dan $X_{3}$ tetap.

Dari hasil pengolahan data diketahui bahwa variabel motivasi, kompetensi dan disiplin guru memiliki sumbangan yang relatif lebih besar dibandingkan variabel kepemimpinan kepala sekolah terhadap kinerja guru. Hal ini menunjukkan bahwa kinerja guru sangat tergantung dari guru sendiri. Untuk menghasilkan output/ lulusan yang kreatif diperlukan pengajaran yang kreatif. Oleh karena itu kinerja guru dalam melaksanakan tugasnya jelas akan turut menentukan keberhasilan pelaksanaan setiap program pendidikan/ pembelajaran.

Kepemimpinan Kepala Sekolah mutlak diperlukan dalam memimpin organisasi bekerja, karena sikap kepemimpinan kepala Sekolah dapat mempengaruhi kinerja guru. Pada akhirnya kinerja guru dapat ditingkatkan dan pencapaian tujuan 
pendidikan dapat dengan mudah terlaksana, serta terwujudnya manusia cerdas komprehensif dan kompetitif akan dapat benar-benar terwujud sebagai hasil dari suatu proses pendidikan/ pembelajaran.

\section{Simpulan dan Saran}

Simpulan

Hasil penelitian menunjukkan bahwa kepemimpinan transformasional kepala sekolah, kompetensi guru, motivasi guru dan kedisiplinan guru berpengarauh signifikan terhadap kinerja guru SMK di Kota Magelang, baik secara sendiri maupun bersama-sama. Sumbangan setiap variabel bebas terhadap variabel kinerja guru berturut-turut sebagai berikut: Kepemimpinan transformasional kepala sekolah 15,2\%; kompetensi guru 51,8\%; motivasi guru $53,9 \%$ dan kedisiplinan guru $45,9 \%$. Secara bersama-sama kepemimpinan transformasional kepala sekolah, kompetensi, motivasi dan kedisiplinan guru meningkatkan kinerja guru sebesar 61,7\%.

\section{Saran}

Berdasarkan temuan dari penelitian ini, maka disarankan kepada Dinas Pendidikan dan Kebudayaan kota Magelang bekerja sama dengan Badan Kepegawaian Daerah (BKD) untuk mengadakan pendidikan dan pelatihan kepemimpinan terutama kepemimpinan trasformasional. Pemerintah disarankan untuk mengadakan pelatihan secara periodik untuk meningkatkan kompetensi guru dan selalu memberikan motivasi kepada guru dalam meningkatkan kinerjanya. Kepada warga sekolah perlu menciptakan budaya disiplin dalam melakukan tugasnya, sehingga tercipta suasana tertib dan teratur di sekolah.

Seluruh pemangku kepentingan di sekolah seperti kepala sekolah, guru, komite sekolah, dinas pendidikan dan orang tua siswa untuk bersinergi dalam meningkatkan kemajuan sekolah terutama mendukung guru dalam meningkatkan kinerjanya.

\section{Daftar Pustaka}

Ali Imron. (1995). Pembinaan guru di Indonesia. Jakarta: PT Dunia Pustaka Jaya

Annisa. (2013). IPM Indonesia 2012 tempati ranking 121 dunia. Jakarta. Diambil tanggal 14 Mei 2013 dari Warta ekonomi online.

E. Mulyasa. (2011). Manajemen E kepemimpinan kepala sekolah. Jakarta: PT Bumi Aksara.

E. Mulyasa. (2007). Menjadi guru profesional. Bandung: PT Remaja Rosdakarya

Fred C. Lunenburg. (2011). Expectancy theory of motivation: motivating by altering expectations. International journal of business and management adminstration vol.15 No. 1, 2011 diambil dari Tanggal 3 februari 2013

Ishak Arep \& Hendri Tanjung. (2003). Manajemen motivasi. Jakarta: Gramedia Widiasarana.

Yukl G. (2009). Kepemimpinan Dalam Organisasi (Terjemahan Budi Supriyanto). New Jersey: Prentice-Hall Inc. (Buku asli diterbitkan tahun 2001). 